\title{
THE IMPACT OF ENVIRONMENTAL FACTORS ON DISTRIBUTION OF FERULA OVINA (BOISS.) BOISS. IN NORTHWEST IRAN
}

\author{
Aghajanlou, F. ${ }^{1}$ - Ghorbani, A. ${ }^{*}{ }^{*}$ Zare Chahouki, M. A. ${ }^{2}$ - MostafaZAdeh, R. ${ }^{1}-$ \\ HASHEMI MAJD, $\mathrm{K}^{3}$ \\ ${ }^{I}$ Department of Natural Resources, Faculty of Agriculture and Natural Resources, University of \\ Mohaghegh Ardabili \\ Ardabil, Iran \\ ${ }^{2}$ Department of Rehabilitation of Arid and Mountainous Regions, University of Tehran \\ Tehran, Iran \\ ${ }^{3}$ Department of Soil Science, Faculty of Agriculture and Natural Resources, University of \\ Mohaghegh Ardabili \\ Ardabil, Iran \\ *Corresponding author \\ e-mail:a_ghorbani@uma.ac.ir
}

(Received $1^{\text {st }}$ Aug 2017; accepted $11^{\text {th }}$ Jan 2018)

\begin{abstract}
Ferula ovina is a forage species, and of the species that is very important in soil conservation and water protection in the rangelands. It has become an endangered species in Iran due to regular cutting and overgrazing. The focus of this study is to investigate the effect of ecological factors on distribution of $F$. ovina in the study area. Samples were collected from three habitats (sites) where $F$. ovina was present along with three sites which did not have it. Three $150 \mathrm{~m}$ transects were established based on randomsystematically method on each site. On each transect, 10 square plots $(2 \times 2 \mathrm{~m})$ were set up, and soil surface features were measured. Climatologic factors were assessed and physiographic factors were extracted for each site. Soil samples were collected from a $0-30 \mathrm{~cm}$ depth for each transect, and the values of soil were determined through laboratory analysis. According to the results, a significant difference was found for the parameters of elevation, slope, aspect, temperature, $\mathrm{EC}, \mathrm{pH}, \mathrm{OC}$, phosphorus, clay, silt and sand $(\mathrm{P} \leq 0.01)$ between habitats where $F$. ovina were present and absent. Results of discriminant analysis suggested that the amount of sand and gravel on soil surface, phosphorous, clay, and EC were effective factors in the distribution of target species.
\end{abstract}

Keywords: ecological factors, species distribution model, discriminant analysis

\section{Introduction}

Environmental variables affect the distribution of plant species (Ashcroft et al., 2011). Therefore, identification of effective variables on spatial distributions of plant communities is an essential issue in ecology (Araujo and Guisan, 2006; Bagheri et al., 2017). Often, there are many combinations of predictor variables that can describe the species distributions, especially when environmental variables are correlated, which leads to uncertainty on the effects of each variable (Platts et al., 2008; Murray and Conner, 2009). Therefore, determining the plant habitats and effective variables on their distributions is the first step in rangeland management (Bagheri et al., 2017). The study of species distribution studies focuses on defining environmental variables that control a plant's movement into adjacent habitats (Arundel, 2005; Mirzaei Mossivand et al., 2017). These variables or controllers outline various spatial aspects of individual plant species distributions (Ghorbani et al., 2015). 
The presence and distribution of plant species in rangeland ecosystems are not random, but variations of climate, soil, topography, anthropological and other attributes play a major role in their expansion (Ghorbani et al., 2015; Akbarlou and Nodehi, 2016). Determination of the variables that control the presence and distribution of rangeland species is one of the main objectives in rangeland ecosystems studies and assessment (Mirzaei Mossivand et al., 2017). However, interactions among plant species and both soil properties and other environmental variables have been well established for some plant species (Bagheri et al., 2017; Mirzaei Mossivand et al., 2017). However, understanding how a variety of plant species in native rangelands responds to soil properties and other environmental variables is not properly known (Ghorbani et al., 2015; Zare-Chahouki and Piri-Sahragard, 2016). Xian-Li et al. (2008) have studied the relationships among vegetation, soil and topography in a dry-warm river valley in south west China. Their results confirmed that plant diversity is mainly correlated with soil water content, and soil water content was mainly determined by soil texture, especially clay content. The results of Yibing (2008) achieved using principal components analysis (PCA) and correspondence analysis (CA) in China, which showed that the soil's physical and chemical properties such as nutrients, moisture, salinity, and $\mathrm{pH}$ were effective on the homogeneity of the habitat.

In the study of relationships between environmental variables and species diversity in Loess plateau of China, Zhang and Dong (2010) reported that elevation, soil type, slope and aspect were important factors in Loessi zone's recovery and had determining factor roles in species distribution. Zare-Chahouki and Zare-Chahouki (2010), in a study on the relationship between environmental variables and species distribution in arid and semiarid areas, concluded that soil texture, salinity, soil depth, available N, K, OM, lime and soil moisture were the major soil variables responsible for differences in the pattern of species. Ghorbani and Asghari (2014) in a study of environmental factors affecting the distribution of Festuca ovina in the southeastern rangelands of Sabalan, reported that this species is more compatible to higher altitudes as well as lower temperatures and does not tolerate soil salinity, and is more compatible with a $\mathrm{pH}$ of 7.1 to 7.3 . Moreover, they concluded that $\mathrm{OM}, \mathrm{P}$, and $\mathrm{K}$ provide better conditions for its growth.

Studies have revealed that soil attributes are of the main parameters in distribution of plant societies, particularly in arid land (Goodal and Perry, 1979) and correlation of some soil chemical characters as well as soil humidity with vegetation cover have been documented in different studies (Dyakov, 2014; Sheikh et al., 2014; Gemedo et al., 2014). However, there are other studies, which emphasized the role of climatic and topographic parameters in addition to physical and chemical specifications in plant species distribution (Davies et al., 2006; Ghorbani et al., 2015; Mirzaei Mossivand et al., 2017).

Ferula L. is the third largest genus of the Apiaceae family (Yaqoob and Nawchoo, 2015; 2016) and includes 180-185 species (Pimenov and Leonov, 2004) that have been reported from USSR, Pakistan, India, western Himalayas, Saudi Arabia, China and Iran (Kurzyna-Mlynik et al., 2008; Yaqoob and Nawchoo, 2016). It has large presence in Asia, particularly in Turkey, Iran and Turkmenistan compared to other genera in the family (Pimenov and Leonov, 1993). Thirty-two species of Ferula have been reported from Iran, where some of its species are known as Endemic (Mozaffarian, 1983; 2007; Yaqoob and Nawchoo, 2016). The popular Persian name of the most of Ferula species is "Koma" and $F$. ovina (Boiss.) Boiss. It is one of these species which is distributed in different regions of Iran (Mozaffarian, 1983; 2007).

Anti-spasmodic, anti-cholinergic and smooth muscle relaxant activities of the aqueous extracts of $F$. ovina have previously been reported and it can be termed a medicinal plant (Al- 
Khalil et al., 1990; Ghannadi et al., 2002; Moghaddam Matin et al., 2014). Studies showed that ecological parameters (rainfall, fog and altitude) affect the quality of resins produced by Ferula species (Safaian and Shokri, 1993; Menglan et al., 2005). Ferula species can be consumed fresh or processed in several forms. Leaves and essential oils in Ferula spp. traditionally have been considered to have medicinal value and there is strong evidence of anti-microbial active compounds (Syed et al., 1987).

F. ovina is consumed for resins or as a grazing plant (Amooaghaie, 2009). As Amooaghaie (2009) reported that $F$. ovina is a forage species, it has become an endangered species in Iran due to regular cutting and overgrazing. Azhir and Shahmoradi (2007) conducted a preliminary descriptive study of Ferula ovina's natural habitat in Tehran province, Iran. They have reported that this species is distributed over 2000 to $3200 \mathrm{~m}$ above sea level, in areas where mean annual precipitation is higher than $400 \mathrm{~mm}$ and mean annual temperature is about $8.0^{\circ} \mathrm{C}$. They also reported that the Ferula species is distributed in areas where EC is lower than $1 \mathrm{ds} / \mathrm{m}$ and $\mathrm{pH} 7$ to 7.7 , on loamy to sandy soil texture. Its distribution observed is in different aspects on the 40 to $50 \%$ slopes. The density of Ferula species in distributed habitats varies from 1600 to 2300 bunch per hectare. The vegetation stage starts from early May and seed ripening takes place in June. However, locals harvest it at the end of the growth stage as winter forage for their sheep and goat. F. ovina is distributed in the Zanjan province as a main species of rangelands (Aghajanlou et al., 2015). Therefore, regarding the importance of $F$. ovina in forage production, soil conservation and water protection in rangelands, and its status in the context of vegetation of Iran, many more studies are needed to understand the factors affecting its growth and distribution.

This study was conducted to investigate the effects of environmental variables on the distribution of $F$. ovina species in the rangelands of Zanjan province in northwest of Iran and determine the most important and effective environmental variables in its distribution. This was also done to chalk out appropriate management strategies for maintenance, restoration and development of its communities on the growing areas. To improve the management of rangelands and offer a baseline for restoration attempts, an understanding of the variables that determine the rangelands species distribution is required. For this purpose, this study was conducted to identify the roles of topography, climate and soil properties, in the distribution of $F$. ovina. Identification of these properties in a given rangeland helps one chart proper management strategies for restoration of similar rangelands.

\section{Materials and methods}

\section{The study area}

The study area was selected in the rangelands of Zanjan province, Iran (Fig. 1). Initially, in order to recognize the distribution of the genus Ferula, an overall study was conducted by literature review (Hedge et al., 1982; Mozaffarian, 2007; Aghajanlou et al., 2015). Moreover, fieldwork was conducted in Zanjan province to select the habitats for Ferula genus. Three habitats with the local name of Soltanieh $\left(48^{\circ} 49^{\prime} 35^{\prime \prime} \mathrm{E} ; 36^{\circ} 18^{\prime} 20^{\prime \prime} \mathrm{N}\right)$, Zakr-Khanchay $\left(48^{\circ}\right.$ $\left.44^{\prime} 41^{\prime \prime} \mathrm{E} ; 36^{\circ} 41^{\prime} 30^{\prime \prime} \mathrm{N}\right)$ and Shilander $\left(48^{\circ} 37^{\prime} 54^{\prime \prime} \mathrm{E} ; 36^{\circ} 50^{\prime} 01^{\prime \prime} \mathrm{N}\right)$ were selected with $F$. ovina distribution (Figs. 1, 2 and 3). The selected habitats' slope ranges from about 47 to $62 \%$ and geographical aspects of the three study sites are southern, southern, and southern to northern, respectively. According to recorded data of meteorological stations (a 10-year period, 2006 to 2015) within and around the selected regions, mean annual precipitation of the selected sites are 403, 347 and $327 \mathrm{~mm}$, respectively. Moreover, the mean annual temperatures of the studied sites are $7.2^{\circ} \mathrm{C}, 8.3{ }^{\circ} \mathrm{C}$, and $6.4^{\circ} \mathrm{C}$, respectively. Maximum and 
minimum precipitation occurs in February and July, respectively. Soil textures of the selected habitats are loam, loam and sandy loam, respectively. Main species of the selected habitats includes perennial herbaceous such as Tanacetum polycephalum, Pimpinella tragium, Campanula steveni, Clastapus vestitus and Nepeta heliotropifolia, dominant grasses such as Agropyrun libanotricum, Festuca ovina, Bromus tomentellus and Poa bulbosa and shrubs such as Acantholimon festucaceum, Thymus kotschyanus, Astragalus baghensis, Astragalus gossypinus, Silene bupleuroides and Hypericum scabrum (Aghajanlou et al., 2015).

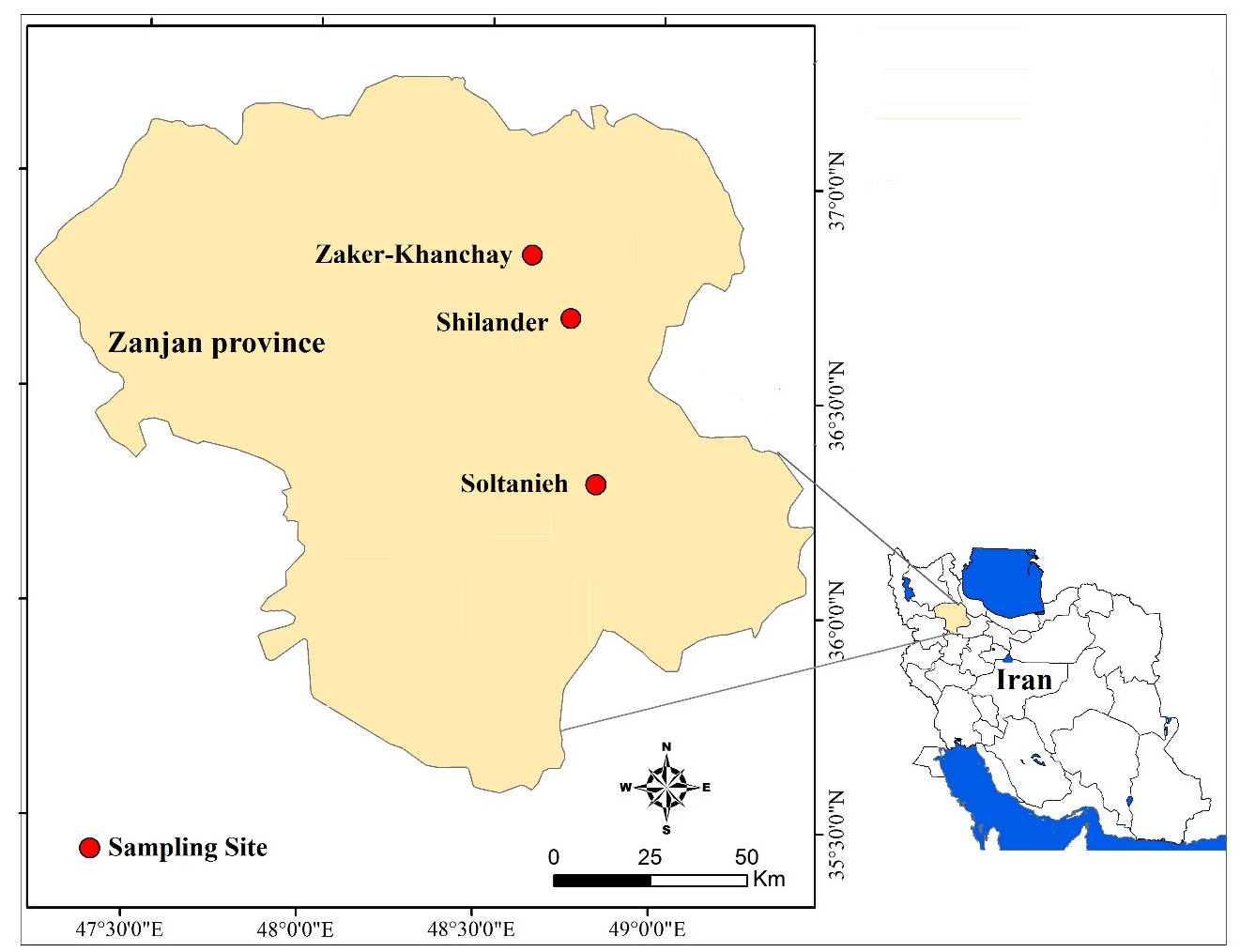

Figure 1. The location of the study area, and selected sites on Zanjan province, Iran

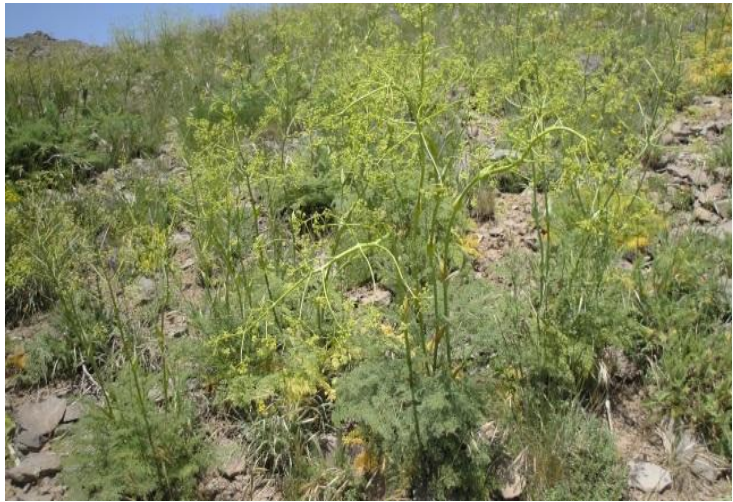

(a)

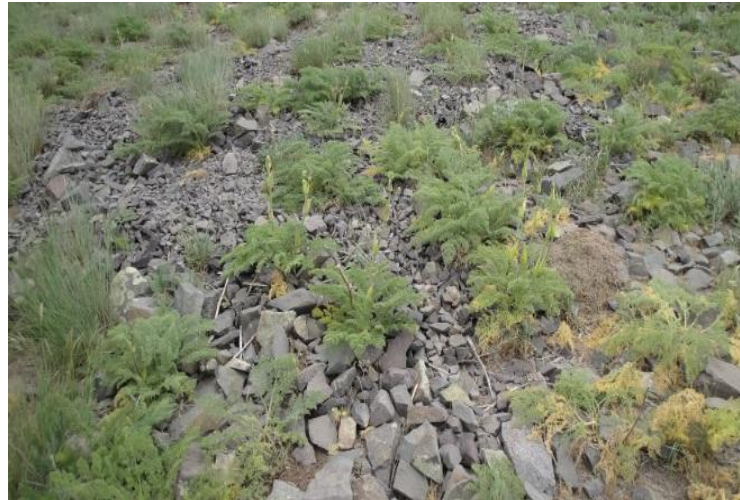

(b)

Figure 2. Ferula ovina (Boiss.) Boiss. a perennial forbs growing in Zanjan province in Iran, $\boldsymbol{a})$ The habitat of Shilander and $\boldsymbol{b}$ ) The habitat of Zaker-Khanchay and) 


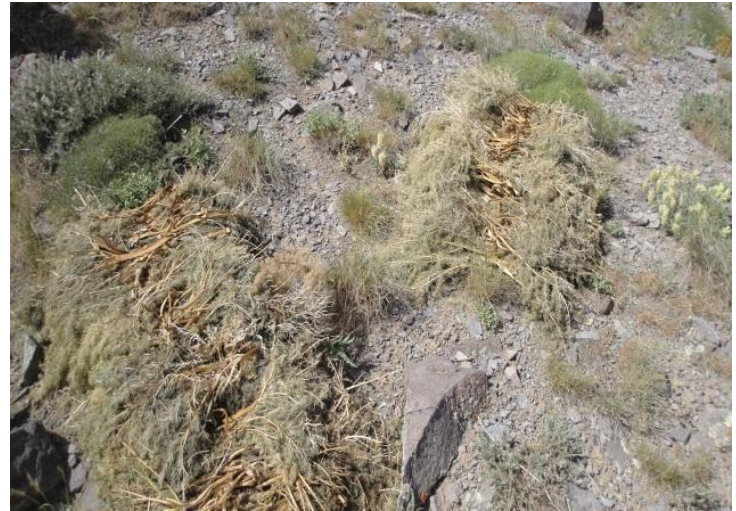

(a)

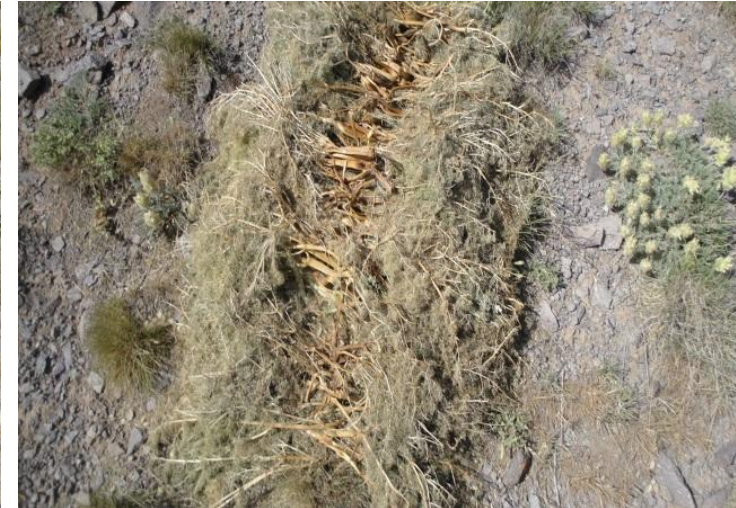

(b)

Figure 3. Over-harvesting of $F$. ovina for providing winter forage for livestock in the study area by locals, $\boldsymbol{a}$ ) and $\boldsymbol{b})$ the habitat of Soltanieh

\section{Sampling}

In each habitat, initially one site with $F$. ovina distribution was selected as the presence of the selected species. Near to each of the selected sites, another site which did not have $F$. ovina species was selected in the same habitat. Therefore, a total of six sites (with $F$. ovina presence and absence) were selected. Three 150-m transects were established based on random-systematically method on each site. On each transect, 10 square plots $(2 \times 2 \mathrm{~m})$ were set up having $15 \mathrm{~m}$ intervals. The total numbers of plots were 180. The established transects were parallel to each other and perpendicular to the slope. Plot size was calculated using minimal area method (Cain, 1938), and the number of plots was obtained using statistical methods. Total canopy cover (TCC), canopy cover of target species (CCTS), and percentage of stone and gravel (PSG) on the soil surface and bare soil were recorded in each site. Soil samples were collected from a 0-30 cm depth (Northup et al., 1999), in the first, middle and end of each transect in all the sites.

Soil properties such as electrical conductivity $(\mathrm{EC})$, soil acidity $(\mathrm{pH})$, soil organic carbon (OC), total neutralizing value (TNV), soil potassium (K), soil phosphorus (P), soil texture (percentage of sand, silt and clay) and saturation humidity (SP) (Burt, 2004; Jafarian et al., 2008), were determined in the soil lab of the Agricultural and Natural Resources Research Centre of Zanjan province. Spatial variations of soil properties were mapped using geostatistical methods including semi-variogram analysis and kriging interpolation in the same spatial resolution (pixel size $10 \mathrm{~m} \times 10 \mathrm{~m}$ ). In this regard, geostatistical analysis was done using $\mathrm{GS}^{+} 5$ software and digital soil layers were prepared in GIS environment. Digital elevation model (DEM) was derived using 1:25000 topographic maps of the National Cartographic Centre of Iran, with $10 \mathrm{~m}$ resolution. Elevation, slope and aspect maps of each sampling plot were derived from the DEM. The annual precipitation, annual mean temperature (Mean T.), mean annual maximum temperature (Max $\mathrm{T}$ ) and mean annual minimum temperature (Min $\mathrm{T}$ ) were extracted using a derived gradient formula from meteorological data (synoptic and climatological stations) and calculated by considering the DEM for each site in GIS environment. All these variables were then extracted for the sampling plots using ArcGIS10. Sampling occurred in May and Jun 2015. 


\section{Data analysis}

The normality of the recorded data was examined using the Kolmogorov-Smirnov test. The one-way ANOVA statistical test was used to analyse the significant difference between the effects of environmental variables on the presence or absence of $F$. ovine. The t-test and Tukey's test were used to evaluate the differences among the variables studied in sites with presence and absence of $F$. ovina. The importance of each measured variable in the distribution of selected species was analysed using discriminant analysis. Stepwise, discriminant analysis (DA) was employed to determine the significance of the variables studied on species distribution and for verifying the grouping of sampling locations (Savic et al., 2008; Edokpa et al., 2009). SPSS18 software was used for data analysis.

\section{Results}

Characteristics of the measured variables in three selected habitats are presented in Table 1. The quantity of annual precipitation, annual mean temperature (Mean. T.), acidity $(\mathrm{pH})$, percentage of total neutralizing value (TNV), percentage of sand and silt, and the percentage of total canopy cover (TCC) had no significant effect $(\mathrm{P} \leq 0.05)$, the amount of other variables such as altitude, percentage of slope, aspect, annual mean minimum temperature (Min. T.), annual mean maximum temperature (Max. T.), electrical conductivity (EC), percentage of organic carbon (OC), quantity of potassium, quantity of exchangeable phosphorus, percentage of clay, percentage of stone and gravel on the soil surface and saturation humidity percentage (SP) with or without the presence of $F$. ovina were significantly different $(\mathrm{P} \leq 0.01)$ in the Zaker- Khanchay site. Meanwhile, in the Shilander site, quantity of annual precipitation, annual mean temperature, acidity, exchangeable phosphorus (p), percentage of stone and gravel on the soil surface (PSG) and percentage of total canopy cover had no significant effect $(\mathrm{P} \leq 0.05)$, other variables such as altitude, percentage of slope, aspect, annual mean minimum temperature, annual mean maximum temperature, electrical conductivity, percentage of total neutralizing value, percentage of organic carbon, quantity of potassium (K), percentage of silt, percentage of sand, percentage of clay and saturation humidity percentage had a significant differences $(\mathrm{P}$ $\leq 0.01$ ) in the sites where the target species was present and absent. According to the results, phosphorus, percentage of clay, percentage of stone and gravel on the soil surface, aspect, annual precipitation, annual mean temperature and total canopy cover was not significantly different $(\mathrm{P} \leq 0.05)$ between the sites where the target species was present and absent in Soltanieh. But other variables such as altitude, percentage of slope, annual mean minimum temperature, annual mean maximum temperature, electrical conductivity, acidity, percentage of total neutralizing value, percentage of organic carbon, quantity of potassium, percentage of sand, percentage of silt and saturation humidity percentage were significantly different $(\mathrm{P} \leq 0.01)$ between the sites where $F$. ovina was present and absent. The results showed that about $37 \%$ of species composition in Soltanieh site belonged to $F$. ovina, which was the highest amount among the studied habitats. $F$. ovina is distributed in the Soltanieh habitat with average slope of about $62 \%$, at an average altitude of 2410 metres above sea level. Average value of the measured variables in Soltanieh habitat were as follows: Electrical conductivity $0.38 \mathrm{ds} / \mathrm{m}, \mathrm{pH} 7.8$, and percentage of total neutralizing value was 5.3. Moreover, the percentage of organic carbon was 2.9, potassium $373 \mathrm{ppm}$ and phosphorus $12.3 \mathrm{ppm}$. The soil texture was determined as loamy, amount of precipitation $403 \mathrm{~mm}$ per year and annual mean temperature was $7.2^{\circ} \mathrm{C}$ (Table 1). 
Table 1. Comparison of measured attributes in the presence and absence of species F. ovina habitats

\begin{tabular}{|c|c|c|c|c|c|c|c|c|c|c|}
\hline Habitat & \multicolumn{2}{|c|}{ Zaker-Khanchay } & \multirow{3}{*}{$\mathbf{t}$} & \multicolumn{2}{|c|}{ Shilander } & \multirow{3}{*}{$\mathbf{t}$} & \multicolumn{2}{|c|}{ Soltaneh } & \multirow{3}{*}{$\mathbf{t}$} & \multirow{3}{*}{$\mathbf{F}$} \\
\hline \multirow{2}{*}{ Variables } & Presence & Absence & & Presence & Absence & & Presence & Absence & & \\
\hline & Mean \pm S.E & Mean \pm S.E & & Mean \pm S.E & Mean \pm S.E & & Mean \pm S.E & $\operatorname{Mean} \pm$ S.E & & \\
\hline Altitude & $2420^{c} \pm 4.00$ & $2467^{b} \pm 0.50$ & $-11.70^{* *}$ & $2471^{\mathrm{b}} \pm 7.10$ & $2495^{\mathrm{a}} \pm 3.80$ & $-2.94^{* * *}$ & $2410^{c} \pm 5.50$ & $2388^{\mathrm{d}} \pm 1.60$ & $3.91^{* *}$ & $92.78^{* *}$ \\
\hline Slope & $47.30^{c} \pm 1.00$ & $42.30^{\mathrm{d}} \pm 0.40$ & $4.54^{* *}$ & $53.30^{b} \pm 0.40$ & $46.70^{\mathrm{e}} \pm 0.40$ & $10.77^{* *}$ & $61.70^{\mathrm{a}} \pm 1.20$ & $53.30^{\mathrm{b}} \pm 0.40$ & $6.73^{* *}$ & $88.90^{* *}$ \\
\hline Aspect & $285^{\mathrm{a}} \pm 3.90$ & $75^{c} \pm 3.90$ & $37.70^{* *}$ & $270^{\mathrm{a}} \pm 0.00$ & $60^{c} \pm 3.90$ & $53.30^{* *}$ & $150^{\mathrm{b}} \pm 15.80$ & $150^{\mathrm{b}} \pm 4.00$ & $0.00^{\mathrm{ns}}$ & $174.00^{* *}$ \\
\hline Precipitation & $347^{\mathrm{b}} \pm 0.50$ & $350^{\mathrm{b}} \pm 0.50$ & $-11.70^{\mathrm{ns}}$ & $327^{c} \pm 0.80$ & $328.70^{\mathrm{c}} \pm 0.40$ & $-2.95^{\mathrm{ns}}$ & $402.80^{\mathrm{a}} \pm 0.60$ & $399.20^{\mathrm{a}} \pm 0.20$ & $3.91^{\mathrm{ns}}$ & $92.76^{* *}$ \\
\hline Mean. T. & $8.30^{\mathrm{a}} \pm 0.00$ & $8.10^{\mathrm{a}} \pm 0.00$ & $11.70^{\mathrm{ns}}$ & $6.40^{c} \pm 0.03$ & $6.20^{\mathrm{c}} \pm 0.02$ & $2.88^{\mathrm{ns}}$ & $7.20^{\mathrm{b}} \pm 0.03$ & $7.10^{\mathrm{b}} \pm 0.01$ & $3.86^{\mathrm{ns}}$ & $92.45^{* *}$ \\
\hline Min. T. & $-1.50^{\mathrm{b}} \pm 0.03$ & $-1.50^{\mathrm{a}} \pm 0.00$ & $11.80^{* *}$ & $-1.50^{c} \pm 0.05$ & $-1.70^{c} \pm 0.03$ & $2.91^{* *}$ & $-1.08^{b} \pm 0.00$ & $-0.92^{\mathrm{a}} \pm 0.04$ & $-3.92^{* *}$ & $93.72^{* *}$ \\
\hline Max. T. & $15.90^{\mathrm{b}} \pm 0.01$ & $15.70^{\mathrm{c}} \pm 0.00$ & $11.98^{* *}$ & $15.70^{\mathrm{c}} \pm 0.01$ & $15.60^{\mathrm{d}} \pm 0.01$ & $3.05^{* *}$ & $15.98^{\mathrm{b}} \pm 0.02$ & $16.07^{\mathrm{a}} \pm 0.00$ & $-3.81^{* *}$ & $95.31^{* *}$ \\
\hline $\mathrm{EC}$ & $0.39^{b c} \pm 0.10$ & $0.47^{\mathrm{b}} \pm 0.10$ & $-4.82^{* *}$ & $0.28^{\mathrm{c}} \pm 0.10$ & $0.87^{\mathrm{a}} \pm 0.09$ & $-6.66^{* *}$ & $0.38^{\mathrm{bc}} \pm 0.01$ & $0.47^{\mathrm{b}} \pm 0.01$ & $-6.07^{* *}$ & $30.15^{* *}$ \\
\hline $\mathrm{pH}$ & $7.17^{\mathrm{b}} \pm 0.04$ & $7.18^{\mathrm{b}} \pm 0.04$ & $-0.23^{\mathrm{ns}}$ & $7.04^{\mathrm{c}} \pm 0.01$ & $7.07^{\mathrm{d}} \pm 0.01$ & $-3.49^{\mathrm{ns}}$ & $7.6^{\mathrm{a}} \pm 0.02$ & $7.5^{\mathrm{b}} \pm 0.02$ & $23.58^{* *}$ & $131.1^{* *}$ \\
\hline TNV & $1.77^{\mathrm{d}} \pm 0.05$ & $1.30^{\mathrm{d}} \pm 0.80$ & $4.79^{\mathrm{ns}}$ & $4.30^{\mathrm{b}} \pm 0.10$ & $2.90^{\mathrm{c}} \pm 0.30$ & $4.20^{* *}$ & $5.30^{\mathrm{a}} \pm 0.01$ & $0.20^{\mathrm{e}} \pm 0.01$ & $37.80^{* *}$ & $23.70^{* *}$ \\
\hline OC & $2.70^{\mathrm{ab}} \pm 0.08$ & $1.30^{\mathrm{c}} \pm 0.06$ & $13.6^{* *}$ & $3.30^{\mathrm{a}} \pm 0.2$ & $2.20^{\mathrm{b}} \pm 0.07$ & $4.94^{* *}$ & $2.90^{\mathrm{a}} \pm 0.30$ & $1.40^{c} \pm 0.07$ & $5.08^{* *}$ & $26.97^{* *}$ \\
\hline $\mathrm{K}$ & $346^{b c} \pm 16.50$ & $209^{\mathrm{d}} \pm 2.40$ & $8.20^{* *}$ & $419^{\mathrm{a}} \pm 23.20$ & $262^{\mathrm{d}} \pm 7.30$ & $6.45^{* *}$ & $373^{\mathrm{ab}} \pm 28.30$ & $278^{\mathrm{cd}} \pm 10.70$ & $3.13^{* *}$ & $20.40^{* *}$ \\
\hline $\mathrm{P}$ & $10.30^{\mathrm{a}} \pm 0.20$ & $3.10^{\mathrm{b}} \pm 0.11$ & $31.00^{* *}$ & $12.60^{\mathrm{a}} \pm 0.40$ & $11.40^{\mathrm{a}} \pm 0.10$ & $1.11^{\mathrm{ns}}$ & $12.33^{\mathrm{a}} \pm 0.70$ & $9.87^{\mathrm{a}} \pm 1.30$ & $1.64^{\mathrm{ns}}$ & $21.50^{* *}$ \\
\hline Sand & $56.70^{\mathrm{a}} \pm 1.80$ & $57.30^{\mathrm{a}} \pm 0.60$ & $-0.34^{\mathrm{ns}}$ & $43.30^{b c} \pm 0.50$ & $47.30^{\mathrm{b}} \pm 0.50$ & $-6.11^{* *}$ & $42.30^{c} \pm 1.20$ & $55.30^{\mathrm{a}} \pm 0.80$ & $-9.30^{* *}$ & $46.59^{* *}$ \\
\hline Silt & $32.30^{\mathrm{c}} \pm 1.40$ & $29.70^{\mathrm{cd}} \pm 0.20$ & $1.90^{\mathrm{ns}}$ & $46.70^{\mathrm{a}} \pm 0.60$ & $37.30^{\mathrm{b}} \pm 0.50$ & $11.7^{* *}$ & $40.30^{\mathrm{b}} \pm 1.06$ & $27.00^{\mathrm{d}} \pm 0.30$ & $12.04^{* *}$ & $85.38^{* *}$ \\
\hline Clay & $11^{\mathrm{cd}} \pm 0.50$ & $13^{c} \pm 0.50$ & $-2.70^{* *}$ & $10.00^{\mathrm{d}} \pm 0.00$ & $15.30^{\mathrm{b}} \pm 0.10$ & $-5.06^{* *}$ & $17.70^{\mathrm{a}} \pm 0.20$ & $17.30^{\mathrm{a}} \pm 0.50$ & $0.00^{\mathrm{ns}}$ & $34.30^{\text {** }}$ \\
\hline PSG & $44.80^{\mathrm{ab}} \pm 3.40$ & $31.70^{b c} \pm 2.60$ & $3.06^{* *}$ & $47.90^{\mathrm{a}} \pm 3.10$ & $45.40^{\mathrm{ab}} \pm 4.00$ & $0.49^{\mathrm{ns}}$ & $36.10^{\mathrm{abc}} \pm 4.60$ & $26.80^{\mathrm{c}} \pm 2.80$ & $1.87^{\mathrm{ns}}$ & $6.38^{* *}$ \\
\hline SP & $31.70^{\mathrm{c}} \pm 0.90$ & $49.30^{\mathrm{a}} \pm 0.50$ & $-16.88^{* *}$ & $49^{\mathrm{a}} \pm 1.20$ & $40.70^{\mathrm{a}} \pm 0.26$ & $5.63^{* *}$ & $49.30^{\mathrm{a}} \pm 2.50$ & $36^{\mathrm{bc}} \pm 0.80$ & $4.98^{* *}$ & $34.20^{* *}$ \\
\hline TCC & $38.20^{\mathrm{a}} \pm 2.80$ & $43.70^{\mathrm{a}} \pm 2.80$ & $-1.43^{\mathrm{ns}}$ & $40.20^{\mathrm{a}} \pm 2.90$ & $35.40^{\mathrm{a}} \pm 2.30$ & $1.39^{\mathrm{ns}}$ & $43.90^{\mathrm{a}} \pm 2.30$ & $39.40^{\mathrm{a}} \pm 1.90$ & $1.54^{\mathrm{ns}}$ & $1.81^{\mathrm{ns}}$ \\
\hline CCTS & $10.80^{\mathrm{b}} \pm 1.50$ & $0.00^{\mathrm{c}} \pm 0.00$ & $7.06^{* *}$ & $10.10^{\mathrm{b}} \pm 1.10$ & $0.00^{\mathrm{c}} \pm 0.00$ & $6.60^{* *}$ & $17.60^{\mathrm{a}} \pm 1.80$ & $0.00^{\mathrm{c}} \pm 0.00$ & $9.93^{* *}$ & $42.50^{* *}$ \\
\hline
\end{tabular}

ns, ** and * are no-significant differences, significant at 1 and 5 percent probability level, respectively

Similar words indicating no difference and different letters indicate significant differences in the rows 
The analysis of variance of variables in different sites under the study indicated a significant difference $(\mathrm{P} \leq 0.01)$ (Table 1). The total canopy cover had not been recognized as significant in the selected sites. According to the results of discriminant analysis (Table 2), four canonical functions were defined, in which the first function explains the $97.5 \%$ variance. Moreover, the second, third and fourth functions justified around $1.8 \%, 0.70 \%$ and $0.0 \%$ of variance. Eigenvalues and canonical correlation were more in the first function than in the second function. On the other hand, Wilks' Lambda values had increased from the first function to the fourth audit function and chi-square value was significant at the first, second, third and fourth functions $(\mathrm{P} \leq 0.01)$. Thus, the average value of groups was significantly different (Table 3$)$. It can be concluded that the first function has higher discrimination power in decomposition of the groups.

Table 2. Eigenvalues and the percentage of variance explained by functions in the discriminant analysis

\begin{tabular}{c|c|c|c|c}
\hline Function & Eigenvalue & Percent of variance & Cumulative \% & Canonical correlation \\
\hline 1 & 17246.86 & 97.50 & 97.50 & 1.00 \\
2 & 319.16 & 1.80 & 99.30 & 0.998 \\
3 & 116.61 & 0.70 & 100.00 & 0.996 \\
4 & 8.62 & 0.00 & 100.00 & 0.947 \\
\hline
\end{tabular}

Table 3. The values of Wilks' lambda in discriminant analysis

\begin{tabular}{c|c|c|c|c}
\hline Test of function (s) & Wilks' lambda & Chi-square & df & Sig. \\
\hline 1 through 4 & 0.00 & 3180.31 & 44 & 0.00 \\
2 through 4 & 0.00 & 1804.79 & 30 & 0.00 \\
3 through 4 & 0.00 & 991.39 & 18 & 0.00 \\
4 & 0.10 & 319.19 & 8 & 0.00 \\
\hline
\end{tabular}

The discriminant coefficients of the variables have shown in Table 4. These results indicated the linear correlation between environmental variables and discrimination function. Precipitation was primarily the most influential factors in the first function. While in the second function, the percentage of slope, silt, sand and percentage of stone and gravel on the soil surface (PSG) turned out to be the most effective factors. Moreover, saturation humidity (SP), mean annual temperature (mean. T.), altitude and organic carbon (OC) were determined as effective factors in the third function, and finally, phosphorus $(\mathrm{P})$, potassium $(\mathrm{K})$, total of neutralizing value (TNV), acidity $(\mathrm{pH})$, electrical conductivity (EC) and clay in the fourth function, to identify sites and distribution of $F$. ovina species.

According to the results of stepwise discriminant analysis (Table 5), discriminant function coefficients for the studied species using canonical functions in the first function is as follows (Eq. 1):

$$
\begin{gathered}
\boldsymbol{Y}=0.171 S P-2.833 E C+5.056 p H-1.619 T N V-1.559 \text { OC }+0.177 \text { Silt }-0.207 \text { Clay }+0.008 \text { Aspect } \\
-0.025 \text { Altitude }+2.967 \text { Mean } T+4.217 \text { Precipitation }-1544.03
\end{gathered}
$$


where, the saturation humidity (SP), electrical conductivity (EC), acidity $(\mathrm{pH})$, total of neutralizing value (TNV), organic carbon (OC), silt, clay, aspect, altitude, mean annual temperature (Mean $\mathrm{T}$ ) and annual precipitation are parameters that determined as effective in the equation, whereas $\mathrm{Y}$ is the presence or absence of target species in equation.

Table 4. Discriminant coefficient of factors in canonic functions

\begin{tabular}{c|c|c|c|c}
\hline \multirow{2}{*}{ Variable } & \multicolumn{4}{|c}{ Functions } \\
\cline { 2 - 5 } & $\mathbf{1}$ & $\mathbf{2}$ & $\mathbf{3}$ & $\mathbf{4}$ \\
\hline Precipitation (mm) & $0.958^{*}$ & 0.089 & -0.088 & -0.059 \\
Slope (\%) & 0.027 & $-0.385^{*}$ & -0.082 & -0.035 \\
Silt (\%) & -0.004 & $0.083^{*}$ & 0.016 & -0.040 \\
Sand (\%) & 0.000 & $-0.064^{*}$ & -0.004 & 0.043 \\
PSG (\%) & 0.039 & $0.063^{*}$ & 0.025 & 0.029 \\
Aspect ( $\left.{ }^{*}\right)$ & -0.007 & 0.025 & $0.149^{*}$ & -0.086 \\
SP (\%) & 0.000 & 0.037 & $-0.070^{*}$ & 0.023 \\
Mean T. ( $\left.{ }^{\circ} \mathrm{C}\right)$ & 0.009 & -0.019 & $0.065^{*}$ & -0.016 \\
Altitude (m) & -0.009 & 0.017 & $-0.061^{*}$ & 0.036 \\
OC (\%) & -0.002 & 0.039 & $-0.046^{*}$ & 0.005 \\
P (ppm) & 0.022 & -0.237 & -0.096 & $-0.560^{*}$ \\
K (ppm) & -0.002 & 0.032 & -0.076 & $-0.332^{*}$ \\
TNV (\%) & -0.002 & 0.228 & 0.019 & $0.325^{*}$ \\
pH & 0.010 & 0.052 & -0.007 & $0.306^{*}$ \\
EC (ds/m) & -0.004 & 0.020 & -0.007 & $-0.179^{*}$ \\
Clay (\%) & 0.007 & 0.000 & -0.015 & $-0.022^{*}$ \\
\hline
\end{tabular}

${ }^{*}$ Largest absolute correlation between each variable and any discriminant function

Table 5. Canonical discriminant function coefficients

\begin{tabular}{c|c|c|c|c}
\hline \multirow{2}{*}{ Variables } & \multicolumn{4}{|c}{ Function } \\
\cline { 2 - 5 } & $\mathbf{1}$ & $\mathbf{2}$ & $\mathbf{3}$ & $\mathbf{4}$ \\
\hline SP & 0.171 & -1.829 & 0.117 & 0.412 \\
EC & -2.837 & 11.749 & -16.538 & -13.053 \\
pH & 5.056 & -30.753 & 13.408 & 3.451 \\
TNV & -1.619 & 12.962 & -4.947 & -0.114 \\
OC & -1.559 & 18.309 & 1.298 & -3.823 \\
Silt & 0.177 & -1.068 & 1.040 & 0.290 \\
Clay & -0.207 & 1.266 & -0.404 & -0.839 \\
Aspect & 0.008 & 0.011 & 0.115 & -0.013 \\
Altitude & -0.025 & 0.202 & 0.161 & 0.460 \\
Mean T. & 2.967 & 6.617 & 78.136 & 102.263 \\
Precipitation & 4.217 & 0.325 & -0.063 & -0.012 \\
(Constant) & -1544.03 & -428.691 & -1182.9 & -2023.9 \\
\hline
\end{tabular}


The results of the classification of the studied habitats using discriminant analysis have been shown in Table 6. The result presented in Table 6, shows the frequency as well as the observed and predicted values of adjustment. Frequency percentage provided in Table 6 represents the level of matching in observed and predicted items. Accordingly, if the data of $F$. ovina was placed in the discrimination function, the function would recognize correctly in $100 \%$ of the membership of the species in the group Zaker-Khanchay. Meanwhile, 100\% membership of species was in Shilander and Soltanieh groups. Moreover, if data of the sites (without the target species) was placed in the discrimination function, the function would detect correctly, in $100 \%$ of cases, membership in the non-presence group. This indicates correct selection of factors affecting the distribution and dissemination of the studied species. In general, the value of a person's membership (100\%) proves accuracy of recognizing the group function.

Table 6. The results of classification using discriminant analysis ${ }^{a}$

\begin{tabular}{|c|c|c|c|c|c|c|c|}
\hline & \multirow{2}{*}{ Group } & \multicolumn{5}{|c|}{ Predicted group membership } & \multirow{2}{*}{ Total } \\
\hline & & 1 & 2 & 3 & 4 & 5 & \\
\hline \multirow{5}{*}{ 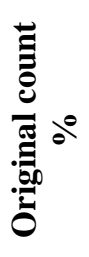 } & 1 & 100.0 & 0.0 & 0.0 & 0.0 & 0.0 & 100.0 \\
\hline & 2 & 0.0 & 100.0 & 0.0 & 0.0 & 0.0 & 100.0 \\
\hline & 3 & 0.0 & 0.0 & 100.0 & 0.0 & 0.0 & 100.0 \\
\hline & 4 & 0.0 & 0.0 & 0.0 & 100.0 & 0.0 & 100.0 \\
\hline & 5 & 0.0 & 0.0 & 0.0 & 0.0 & 100.0 & 100.0 \\
\hline
\end{tabular}

${ }^{\mathrm{a}} 100.0 \%$ of original grouped cases correctly classified

Group1, The Zaker.Khanchay habitat (with presence of $F$. ovina). Group2, Adjacent Zaker-Khanchay and Shilander habitat (with absence of $F$. ovina). Group3, The Shilander habitat (with presence of $F$. ovina). Group4, The Soltanieh habitat (with presence of $F$. ovina). Group5, Adjacent Soltanieh habitat (with absence $F$. ovina)

\section{Discussion and conclusion}

The presence, absence and plant species distribution in natural ecosystems depend on factors such as climate, edaphic, available resources, competition among species, natural and non-natural stress, and plant biological zone. In a large scale, the distribution of plant communities is more influenced by the climate and secondly by the edaphic factors, while in local scale, edaphic factors and available sources are the most important factors and other factors are the next critical ones (Fridley, 2001; Mirzaei Mossivand et al., 2017).

The results of the analysis of variance for the parameters of the studied sites showed that from the 20 evaluated parameters (Table 1), except for the canopy cover of species, other variables have a significant difference $(\mathrm{P} \leq 0.01)$. Thus, according to the results, it can be concluded that the ecological conditions of each habitat are different. On the other hand, the results of the Canonical Discriminant Function Coefficients (Table 5) indicated that in the presence or absence of the Ferula ovina species in the studied habitats, the percentage of saturation humidity (SP), the percentage of electrical conductivity (EC), acidity $(\mathrm{pH})$, percentage of total neutralizing value (TNV), percentage of organic carbon (OC), percentage of silt, aspect, altitude, mean annual temperature (mean T.), and the annual precipitation were effective factors.

Although the $F$. ovina species was one of the dominant species of vegetation in the southern regions of the study area, in other geographic areas it was also distributed in 
a sporadic manner. Indubitably, the geographical aspect affects the amount of soil humidity, soil temperature, and light intensity received by the plant. The difference in the light intensity in different aspects of hillside and crests affect the local climate and plant communities (Gonzales-Alcaraz et al., 2014). It seems that alterations in the local climate conditions are among the main factors influencing the distribution and presence or absence of the target species. Based on field observations, it has been proved that $F$. ovina mainly dominated the hillsides that had a greater light intensity. Investigations conducted on the descriptive autecology study of $F$. ovina in Iran are in agreement with our findings. Azhir and Shahmoradi (2007) concluded that the distribution and presence or absence of the $F$. ovina species depend on the geographical aspect and percentage of slope.

Precipitation, mean annual temperature, and altitude not only affected the presence or absence of the species, but the impact of precipitation on the distribution of the studied species in the locations was the most effective factor. These results are in agreement with the findings of Davies et al. (2007) which state that topographic characteristics (e.g., elevation, slope and aspect) are closely associated with the local climate (e.g. precipitation, evaporation and temperature) that greatly impacts plants. This is also in conformity with $\mathrm{Xu}$ et al. (2013), who stated that precipitation and temperature are consistently highlighted as influential in the distribution of plants (Xu et al., 2013).

The percentage of silt in the soil in the habitat of $F$. ovina was higher than habitats where it was absent and the clay and sand percentage of soil in sites where the target species was present was lower than the habitats where it was absent. In other words, it seems that the studied species prefer soils that have a medium texture, as the soil texture was an effective factor in the distribution and presence or absence of the F. ovina. Soil texture due to the influence of moisture amount and available nutrients in plants, water holding capacity in the soil, food cycle, ventilation, depth of plant rooting, and the amount of runoff flowing after rainfall on the soil surface as well as the distribution of plants plays a role (EL-Sheikh and Youssef, 1981; EL-Ghani, 2003). Accordingly, previous reports have mentioned that soil texture is a key factor in the presence or absence of the plant in the studied locations (Taghipour et al., 2008; Ghorbani and Asghari, 2014).

The quantity of the total of neutralizing value (TNV) in the habitats of $F$. ovina is significantly higher than the places without the species. It seems that the TNV has been identified as an effective factor in discriminating locations. However, it has had less effect on the distribution of species in locations with the presence of the $F$. ovina species. Previous studies on $F$. ovina have also emphasized that this species had a significant percentage of canopy cover on a relatively calcareous geological formation in comparison to other places. Likewise, it was the dominant species in many areas of Iran (Azahir and Shahmoradi, 2007).

The electrical conductivity (EC) represents the amount of conductive solute contained in the soil solution, one of the main ones being salt (sodium chloride). Although the studied sites were not saline areas, the amount of electrical conductivity in the presence of the species was between 0.28 to $0.39 \mathrm{ds} / \mathrm{m}$, in mutuality, and in the absence of the species it was between 0.47 to $0.87 \mathrm{ds} / \mathrm{m}$. Salinity and soil salinity are commonly found on agricultural land, and the lands on which they are located (mountainous lands) are considered as saline soils in non-saline soils, but it seems that even this difference has caused electrical conductivity (EC) to be among the factors influencing the presence or absence of the species in the studied locations. 
Another important factor in the distribution of the species in the habitats was the percentage of slope. The highest percentage of canopy cover of the target species was observed in the habitat that had a higher slope percentage among all the habitats. Usually, slope is considered a limiting factor in the distribution and establishment of plants. As the slope increases, the depth of soil and soil moisture decreases, and as a result, the plants' establishment is restrained. Our results are in conflict with this issue.

This species, although in the growth stages due to the presence of the volatile compounds, is not heavily grazed, but after the end of the growing period and when the branches and leaves become yellow, they play a major role in grazing in the late summer and early autumn. Of course, it plays a more important role in fodder forage in local livestock feeders (Fig.3). Thus, the slope as a natural factor in this case has led to a reduction in overgrazing and the inappropriate use of rangelands, and it has been a limiting factor in the studied locations. However, it did not affect the distribution of the target species.

This rangeland species has an extensive canopy cover and is important not only in forage production, but due to the wide canopy cover and the extent of the root system, it increases the humus and soil organic matter. It can also be considered as one of the most important species in decreasing soil erosion.

Though organic carbon had a relatively small effect on the distribution of the species in the studied locations, it was one of the factors influencing the presence or absence of the species studied. The results of many studies showed that organic carbon was one of the soil characteristics affecting the distribution and presence or absence of vegetation in the evaluated areas. These findings were in agreement with the results of Ayyad (1976), Mahdavi et al. (2009), Kooch et al. (2007). A study of the ecological distribution of some indicator species and their effective soil factors showed that the distribution and presence or absence of vegetation in those areas correlated with the soil properties such as soil texture, quantity of phosphorus, percentage of organic carbon, and acidity.

The increased uses of fossil fuels, land use change and degradation of vegetation have led to the release of a huge amount of greenhouse gases into the atmosphere (Hamburg et al., 1997). Carbon dioxide is the most important greenhouse gas and increasing its density in the atmosphere has increased global warming and climate change. Moreover, climate change is one of the most important challenges that have very adverse effects on the environment and human life on the planet (Hamburg et al., 1997; IPCC, 2007; UNDP, 2000). The global estimate of carbon in rangeland soils is about $30 \%$ of its total amount in the planet (Sarapatka and Cizkova, 2013). One of the most effective ways to reduce greenhouse gases is to sequester them in soil or plant organs (Rossi et al., 2009). Plant biomass is one of the factors affecting the storage of organic carbon in soil and the species studied is one of the species that has a high biomass in rangelands. The high organic carbon content of the soil and its significant difference in sites with the presence of target species relative to sites without its presence indicates the important role of this species in the accumulation of organic carbon in these areas. In this regard, Ghoreyshi et al. (2013) also indicated that with increasing the organic matter, more carbon was stored in the soil of the studied sites.

In other studies, the percentage of stone and gravel on the soil surface (PSG) was another factor affecting the distribution of the studied species in the locations, which was in agreement with the results of Assadian et al. (2017). In many ecological studies, the percentage of stone and gravel on the soil surface is not very noticeable. Its amount plays an important role in maintaining soil moisture, water penetration in the soil, and 
soil conservation in sloping lands. Especially in arid regions like Iran, PSG is important for maintaining the moisture in the under soil, and can play an important role in the survival of plants.

Although many similar results from other studies were cited to support our abovementioned discussion, there still existed some different aspects between our studies and other ones. For example, Xu et al. (2013) documented precipitation and temperature are consistently highlighted as influential in the distribution of plants, while the percentage of slope, silt, sand and the percentage of stone and gravel on the soil surface were more important than temperature in our study. However, it is very difficult to really discern the differences in the results from different studies, because the vegetation, soil, and topography relationship is very complicated per se; the aims of the other studies and the associated measures taken were very different and the local conditions also varied from one study to another. In this regard, Amooaghaie (2009) has reported that the F. ovina species is among the endangered ones distributed in many areas in Iran. On the other hand, it seems in view of different reasons including habitat degradation due to inappropriate and unsuitable usage such as over grazing and even excessive harvesting for winter forage of livestock in areas by local people, it is certain that some characteristics of environmental factors such as topography, climate, soil texture, the amount of gypsum and lime, and some other characteristics of the soil are in compatible, and are the nature of the ecosystems.

However, how human activities and exploitation of rangeland ecosystems will cause some of the factors such as soil organic matter, potassium and phosphorus in this study to be affected by this process, and the distribution, presence and absence of species will affect in the locations. This is an important theory or framework to direct the practice of ecosystem restoration and management. It is difficult to directly restore the original species in the degraded dry lands; hence, several steps following a natural succession sequence would be necessary. In addition, plant degradation is not only an ecological but also an economic and social problem; some relevant conservation policies are needed to reduce human disturbance on the ecosystem. Thus, in the restoration and management of species habitats, not only vegetation and environmental factors but also human activities should be considered.

This study has tried to provide some useful information on the distribution of $F$. ovina. Results will be useful in developing future $F$. ovina management guidelines, which can be used to rehabilitate and develop the habitats of this rangelands species in the regions, and this can play an important role in the issue of carbon sequestration, soil erosion and soil conservation in the rangelands. Other factors influencing the distribution of the species such as biotic interactions, genetic adaptation, and the species' dispersal abilities should be taken into account in order to draw relevant conclusions to have a better conservation, as well as oriented decisions.

\section{REFERENCES}

[1] Aghajanlou, F., Fayaz, M., Mussavi, A., Abdinejad, P. (2015): Ecological Regions of Iran: Vegetation Types of Zanjan Province. - Research Institute of Forest and Rangelands of Iran, Tehran.

[2] Akbarlou, M., Nodehi, N. (2016): Relationship between some environmental factors with distribution of medicinal plants in Ghorkhud protected region. - Journal of Rangeland Science 6(1): 63-72. 
[3] Al-Khalil, S., Aqel, M., Afifi, F. (1990): Effects of an aqueous extract of Ferula ovina on rabbit and guinea pig smooth muscle. - Journal of Ethnopharmacology 30(1): 35-42.

[4] Amooaghaie, R. (2009): The effect mechanism of moist-chilling and GA3 on seed germination and subsequent seedling growth of Ferula ovina Boiss. - The Open Plant Science Journal 3: 22-28.

[5] Araujo, M. B., Guisan, A. (2006): Five (or so) challenges for species distribution modeling. - Journal of Biogeography 33: 1677-1688.

[6] Arundel, S. T. (2005): Using spatial models to establish climatic limiters of plant species distributions. - Ecological Modelling 182: 159-181.

[7] Ashcroft, M. B., French, K. O., Chisholm, L. A. (2011): An evaluation of environmental factors affecting species distributions. - Ecological Modeling 222(3): 524-531.

[8] Assadian, G., Javadi, S. A., Jafary, M., Arzani, H., Akbarzadeh, M. (2017): Relationship between environmental factors and plant communities in enclosure rangelands. - Journal of Rangeland Science 7(1): 20-34.

[9] Ayyad, M. (1976): The vegetation and environment of the western Mediterranean coastal land of Egypt. IV. The habitat of non-saline depressions. - Journal of Ecology 64: 713722.

[10] Azhir, F., Shahmoradi, A. A. (2007): Autecological study of Ferula ovina in rangelands of Tehran province. - Iranian Journal of Range and Desert Research 21(3): 359-367.

[11] Bagheri, H., Ghorbani, A., Zare Chahouki, M. A., Jafari, A.A. Sefidi, K. (2017): Halophyte species distribution modeling with MaxEnt model in the surrounding rangelands of Meighan playa, Iran, - Applied Ecology and Environmental Research 15(3): 1473-1484. DOI: http://dx.doi.org/10.15666/aeer/1503_14731484.

[12] Burt, R. (2004): Soil Survey Laboratory methods. Soil Survey Investigations Rep. 42, vs. 4.0. USDA. - Natural Resources Con- serv. Serv., Washington, DC.

[13] Cain, S. A. (1938): The species-area curve. - American Midland Naturalist 21: 81-146.

[14] Davies, K. W., Bates, J. D., Miller, R. F. (2006): Vegetation characteristics across part of the Wyoming big sagebrush alliance. - Rangeland Ecology and Management 59: 567575.

[15] Davies, K. W., Bates, J. D., Miller, R. F. (2007): Environmental and vegetation relationships of the Artemisia tridentate Spp. Wyomingensis alliance. - Journal of Arid Environments 70: 478-494.

[16] Dyakov, N. R. (2014): Gradient analysis of vegetation on the south slope of Vitosh Mountain, Southwest Bulgaria. - Applied Ecology and Environmental Research 12(4): 1003-1025.

[17] Edokpa, I. W., Erimafa, J. T., Iduseri. A. (2009): Application of discriminant analysis to predict the class of degree for graduating students in a university system. - International Journal of Physical Sciences 4(1): 016-021.

[18] EL-Ghani Monier, M. (2003): Soil-vegetation relationships in a coastal desert plain of southern Sinai, Egypt. - Journal of Arid Environment 55: 607-628.

[19] El-Sheikh, A. M., Youssef, M. M. (1981): Halophytic and Xerophytic vegetation near AlKharj springs. - Jour. College of Science 12: 5-21.

[20] Fridley, J. D. (2001): The influence of species diversity on ecosystem productivity: how, where and why? - Oikos 93: 514-526.

[21] Gemedo, D., Brigitte, L. M., Johannes, I. (2014): Relationships between vegetation composition and environmental variables in the Borana rangelands, Southern Oromia, Ethiopia Sinet, Ethiopia. - Journal of Science 37(1): 1-12.

[22] Ghannadi, A., Sajjadi, S. E., Beigihasan, A. (2002): Composition of the essential oil of Ferula ovina (Boiss.) Boiss. from Iran. - Iranian DARU Journal of Pharmaceutical Sciences 10(4): 165-167.

[23] Ghorbani, A., Asghari, A. (2014): Study the influence of ecological factors on Festuca ovina distribution in southeast rangelands of Sabalan. - Iranian Journal of Range and Desert Research 21(2): 368-381. 
[24] Ghorbani, A., Abbassi Khalaki, M., Omidi, A., Zare hesari, B. (2015): Compare some ecological factors affecting the distribution of plants species Artemisia austriaca and Artemisia fragrans Wild. Jacq. in southeastern rangelands of Sabalan. - Iranian Journal of Rangeland 9(2): 129-141.

[25] Ghoreyshi, R., Goly, E., Motamedi, J., Keivan Behjou, F. (2013): Carbon sequestration capacity in rangeland ecosystems and its relation with soil physical and chemical characteristics in rangelands of Khoy. - Iranian Journal of Applied Soil Research 1(2): 34-44.

[26] Gonzales-Alcaraz, M. N., Jimenez-Carceles, F. J., Alvarez Y., Alvarez-Rogel, J. (2014): Gradient of soil salinity and moisture and plant distribution in a Mediterranean SemiArid Saline watershed: A model of soil- plant relationships for contributing to the management. - Catena 115: 150-158.

[27] Goodal, D. W., Perry, R. A. (1979): Arid-Land Ecosystem. - Syndics of the Cambridge University Press, Cambridge.

[28] Hamburg, S. P., Harris, N., Jaeger, J., Karl, T. R., McFarland, M., Mitchell, J. F. B., Oppenheimer, M., Santer, S., Schneider, S., Trenberth, K. E., Wigley T. M. L. (1997): Common Questions about Climate Change. United Nation Environment Program. World Meteorology Organization, Geneva.

[29] Hedge, I. C., Lamond, J. M., Rechinger, K. H. (1982): Ferula (Flora Iranica Umbelliferae series no. 162). - Akademische Druck- u. Verlagsanstalt, Graz.

[30] IPCC (2007): Climate Change. The Scientific Basis. IPCC Fourth Assessment Report. Cambridge University Press, Cambridge.

[31] Jafarian, Z., Arzani, H., Jafari, M. (2008): Analyzing the relationship between distribution or plant communities and climatic and physiographic factors using classification and ordination methods in Rineh Rangelands. - Iranian Journal of Rangeland 6:125-141.

[32] Khatibi, R., Ghasemi Arian, Y., Jahantab, E., Haji Hashemi, M. R. (2012): Investigation on relationships between soil properties and vegetative. - Iranian Journal of Range and Desert Research 19(1): 72-81.

[33] Kooch, Y., Bahmanyar, H. J. M. A., Pormajidian, M. R. (2007): Ecological distribution of indicator species and effective edaphical factors on the Northern Iran lowland forests. - Journal of Applied Science 7: 1475-1483 (in Persian).

[34] Kurzyna-Mlynik R., Oskolaski, A. A., Downie, S. R., Kopacz, R., Dzka, A. W., Spalik, K. (2008): Phylogenetic position of the genus Ferula (Apiaceae) and its placement in tribe Scandiceae as inferred from nr DNA ITS sequence variation. - Plant Systematics and Evolution 274: 47-66.

[35] Mahdavi, A., Heidari, M., Bastam, R., Abdollah, H. I. (2009): Study of vegetation cover on the soil condition and physiographic of habitat (Case Study: Kabir kuhe Ilam protected area). - Journal of Forest Research and Poplar 17(4): 581-593 (in Persian).

[36] Menglan, S., Watson, M. F. (2005): Flora of China, Vol. 14, pp. 174-180. - Science Press and Missouri Botanical Garden Press, Beijing and St. Louis. http://flora.huh.harvard.edu/china/index.html.

[37] Mirzaei Mossivand, A., Ghorbani, A. Keivan Behjou, F. (2017): Effects of some ecological factors on distribution of Prangos uloptera and Prangos pabularia in rangelands of Ardabil province, Iran, - Applied Ecology and Environmental Research 15(4): 957-968. DOI: http://dx.doi.org/10.15666/aeer/1504_957968.

[38] Moghaddam Matin, M., Nakhaeizadeh, H., Bahrami, A. R. (2014): Ferutinin, an apoptosis inducing terpenoid from Ferula ovina. - Asian Pacific Journal of Cancer Prevention 15(5): 2123-2128.

[39] Mozaffarian, V. (1983): The Family of Umbelliferae in Iran - Keys and Distribution. Research Institute of Forests and Rangelands of Iran, Tehran.

[40] Mozaffarian, V. (2007): Flora of Iran (Umbelliferae), Vol. 54. - Research Institute of Forest and Rangelands of Iran, Tehran. 
[41] Murray, K., Conner, M. M. (2009): Methods to quantify variable importance: implications for the analysis of noisy ecological data. - Ecology 90: 348-355.

[42] Northup, B. K., Brown, J. R., Holt, J. A. (1999): Grazing impact on the spatial distribution of soil microbial biomass around tussock grasses in a tropical grassland. Journal of Applied Soil Ecology 13: 259-270.

[43] Pimenov, M., Leonov, M. (1993): The Genera of Umbelliferae. - Royal Botanic Gardens, Kew.

[44] Pimenov, M., Leonov, M. (2004): The Asian Umbelliferae biodiversity database (ASIUM) with particular reference to South-West Asian taxa. - Turkish Journal of Botany 28: 139-145.

[45] Platts, P. J., McClean, C. J., Lovett, J. C. (2008): Predicting tree distributions in an East African biodiversity hotspot: model selection, data bias and envelope uncertainty. Ecological Modelling 218: 121-134.

[46] Rossi, J., Govaerts, A., De Vos, B., Verbist, B., Vervoort, A., Poesen, J., Muys, B., Deckers, J. (2009): Spatial structures of soil organic carbon in tropical forests-a case study of Southeastern Tanzania. - Catena 77: 19-27.

[47] Safaian, N., Shokri, M. (1993): Botanical and ecological study of species of the genus Ferula (medicinal plants) in Mazandaran province. - Acta Horticulture 333: 79-81.

[48] Sarapatka, B., Cizkova, S. (2013): The influence of different types of grassland on soil quality in upland areas of Czech Republic. - Journal of Environmental Biology 35: 453-459.

[49] Savić, M., Brcanov, D., Dakić, S. (2008): Discriminant Analysis - Applications and Software Support. - Management Information Systems 3(1): 029-033.

[50] Sheikh, S. A., Rabia, M., Rabia, S. (2014): Environmental diversification and spatial variations in riparian vegetation. - Pakistan Journal of Botany 46(4): 1203-1210.

[51] Syed, M., Hanif, M., Chaudhary, F. M. (1987): Antimicrobial activity of the essential oils of Umbelliferae family: Part IV. Ferula narthex, Ferula ovina and Ferula oopoda. Pakistan Journal of Scientific and Industrial Research 30: 19-23.

[52] Taghipour, A., Mesdaghi, M., Heshmati, G. A. (2008): The effect of on distribution of range species at Hazar Jarib area of Behshahr. - Iranian Journal of Agriculture Science and Natural Resources 15(4): 195-205.

[53] UNDP (2000): Carbon sequestration in the decertified rangelands of Hossein Abad, through community-based management. - Program Coordination, pp. 1-7.

[54] Xian-Li, X., Ke-Ming, M., Bo-Jie, F. (2008): Relationships between vegetation, soil, and topography in a dry warm river valley, SW China. - Catena 75: 138-145.

[55] Xu, Z. Z., Shimizu, H., Yagasaki, Y., Ito, S., Zheng, Y. R., Zhou, G. S. (2013): Interactive effects of elevated $\mathrm{CO} 2$, drought, and warming on plants. - Journal of Plant Growth Regulation 32: 692-707. DOI: 10.1007/s00344-013-9337-5.

[56] Yaqoob, U., Nawchoo, I. A. (2015): Phytochemical screening of the root tuber extracts of Ferula jaeschkeana Vatke. - Journal of Essential Oil Bearing Plants 19(1): 208-211. DOI: https://doi.org/10.1080/0972060X.2014.908149.

[57] Yaqoob, U., Nawchoo, I. A. (2016): Distribution and taxonomy of Ferula L.: A Review, Research \& Reviews. - Journal of Botany 5(3): 15-23.

[58] Yibing, Q. (2008): Impact of habitat heterogeneity on plant community pattern in Gurbantunggut Desert. - Geographical Science 14(4): 447-45.

[59] Zare-Chahouki, M. A. (2010): Data Analysis in Natural Resources Research Using SPSS Software. - University of Tehran Press, Tehran.

[60] Zare-Chahouki, M. A., Piri-Sahragard, H. (2016): Maxent modelling for distribution of plant species habitats of rangelands (Iran). - Polish Journal of Ecology 64(4): 453-467.

[61] Zare-Chahouki, M. A., Zare Chahouki, A. (2010): Predicting the distribution of plant species using logistic regression. - Desert 15: 151-158.

[62] Zhang, J. T., Dong, Y. (2010): Factors affecting species diversity of plant communities and the restoration process in the loess area of China. - Ecological Engineering Special Issue: Vegetation and Slope Stability 36: 345-350. 